\title{
Ethnocentrism and Nation. Reflection on Blocking Factors the Birth of the African Subject
}

\author{
Mbemba-Mpandzou Anselme \\ Department of Philosophy, Faculty of Literature and Humanities, Marien Ngouabi University, Brazzaville, Congo \\ Email: lembav@gmail.com
}

How to cite this paper: Anselme, M.-M. (2018). Ethnocentrism and Nation. Reflection on Blocking Factors the Birth of the African Subject. Open Journal of Philosophy, 8, 594-613.

https://doi.org/10.4236/ojpp.2018.85043

Received: September 24, 2018

Accepted: November 27, 2018

Published: November 30, 2018

Copyright $\odot 2018$ by author and Scientific Research Publishing Inc. This work is licensed under the Creative Commons Attribution International License (CC BY 4.0).

http://creativecommons.org/licenses/by/4.0/

\begin{abstract}
The article questions the concepts of ethnocentrism and nation in order to identify the universes of meaning that they contain and assess their relevance in the construction of the nation. From the perspective of this construction, obstacles strew this course and prevent the birth of the African subject, the very one who is the key. The purpose of the article is to give the necessary tools to hatch a national conscience, pledge of strengthening of patriotic bond and citizen. Without this national consciousness, it is impossible for the young African republics to become nations and to embark on the path of emergence.
\end{abstract}

\section{Keywords}

Ethnocentrism, Cultural Identity, Consciousness, Subject, Nation

\section{Introduction}

Every society is based on solidarity; every organized collectivity presupposes the consciousness of a general interest, distinct from particular interests. These notions are very present in African societies; they are also felt in a much more concrete way than is the case in industrial societies where anonymity reigns and where spontaneous solidarities have disappeared. But this feeling of solidarity, based on what the West calls "national sentiment", manifests itself in Africa not at the level of the state (nation-state) but at lower levels: the different ethnic groups. Thus, the "national unity" in Africa doesn't yet correspond to any concrete social reality, whereas on the contrary, regional solidarities remain the powerful (Michalon, 1984: pp. 82-83).

This statement highlights the existence of the feelings of solidarity and com- 
mon interest that characterize any political community. However, while these feelings are present in Africa at the lower level, including that of ethnic affiliations, they are absent from the consciousness of ruling class. Absence of these feelings at the top of the nation-state is all the more marked as it makes the realization of "national unity" difficult, as it is true that the leaders are held hostage by the chain of clan and/or village solidarities. However, at the time of the accession of the colonized countries to "independence", the first leaders as well as those who took over, have not ceased to call for "national unity", the foundation of the nation. If one owes through independence the re-building of "national unity", it is in the idea that it had been momentarily lost from African soil.

The main objective of the study, through question on the paradox that exists between calls of the leaders to invite people to "unity" and their political practice, is to give the necessary tools to hatch a national conscience, pledge of strengthening of patriotic bond and citizen. It is we would like to question by asking ourselves a question of substance: can the construction of the nation be based on an ethnocentric approach to power? This main question calls for two secondary questions: Is ethnocentrism an inclusive concept devoid of any ideological connotation? To what can ethnocentrism serve, is it not to mislead the good sense of the citizens and to delay the birth of the African subject?

To study the involvement of ethnocentrism, neocolonial policies and bad governance in the subjection of the African subject, we adopt a socio-genealogical and analytical and critical approach. Indeed, "any sociological investigation must be to define the things it deals with, so that we know and that the researcher knows what it is about" (Berger \& Luckman, 2006: p. 72). Genealogically, because it allows us to go back in time to find the hidden origin of a fact, a phenomenon, and a concept. She is analytical and critical in order to identify the various meanings of the concepts of ethnocentrism and nation and to evaluate their relevance in the construction of the African nation. It is in this context that our reflection focuses on five areas. The premier strives to identify and analyze the theories of references that underlie ethnocentrism and the nation. The second axis reports all the positions taken in the field studied (of positions and knowledge), determining and determined within these theories. The third axis interprets the various debates on the construction of the African nation, while analyzing the collateral effects. The fourth axis focuses on the phenomenon of decolonization in Africa and the survivals of totalitarian regimes. Finally, the fifth axis reflects on the African intellectual (and/or patriot) and his role in the birth of the African subject.

\section{Theories of References}

\subsection{Ethnocentrism}

It is important from the outset to note the confusion that is often made between the terms "ethnocentrism" and "ethnic consciousness". Indeed, in the syntagma "ethnic consciousness", there is the adjective "ethnic" formed from the term 
"ethnicity". This one is a creation of the colonial ethnology. Ethnology as a science that studies ethnicities has indeed preceded the use of the word derived from Greek ethnos, the latter being like the reference phantom, the mold where the research had to flow (Chrétien \& Prunier, 1989: p. 6). Thus, from its Greek etymology ethnos, "ethnicity" designates both a people or a primitive nation to "barbarian" customs and customs. In ancient Greek culture, the so-called primitive societies characterized by a lack of organization were designated by the term "ethnè" in opposition to the "polis" which passes to signify the fundamentally well-organized city-state whose members enjoyed the status of Athenian citizens.

According to P. Mercier cited by J.-L. Amselle and E. Mbokolo (1999: p. 14), in the 16th and 17th centuries, the terms "nation" and "tribe" were interchangeable. The word tribe originates from the Latin tribes and refers to a grouping of individuals by clans claiming a common mythical ancestor, relations of kinship characterize its organization. The concept of ethnicity is equivalent to it. Indeed, it is in 1896 that the term "ethnicity" appeared in the French language under the pen of G. Vacher de Lapouge who uses it to designate "race". The word "ethnicity" had such a fortune that it ended up being afraid of its denomination too original. Anthropologists, sociologists and other social scientists have copiously used the words "nation", "tribe", "race", "people", "ethnicity" without being able to clarify their semantics. Abandoning the original sense of race/nation, the term ethnicity ended up categorizing human groups living in non-European societies. Working to elucidate the motivations of those who gave a new meaning to the word ethnicity, Guy Nicolas (1973: pp. 99-100) notes that the concept of ethnicity has been used for "peoples considered as 'savage', 'barbarian' or 'primitive', [who] had until then been kept out of the attention of men of science" (p. 95). In fact, according to J.-L. Amselle and E. Mbokolo (1999 : p. 14), the term ethnicity has been coined to classify certain societies apart by denying them a specific quality, by taking away from them by which they could participate of a common humanity.

As we can see, when the term "ethnicity" is used to understand the sociological realities of peoples who don't belong to Western space, it has a pejorative connotation. "Ethnology, taken literally, is therefore a science of 'a-political' societies and deprived of the possibility of being 'subjects' in their history" (Amselle \& Mbokolo, 1999: p. 15). Beyond the various senses of which it is affected, ethnicity is

"A group of individuals linked by a complex of common characters-anthropological, linguistic, politico-historical, etc.-whose association constitutes a system of its own, an essentially cultural structure: a culture. Ethnicity is then the community, or better the community, united by a particular culture" (Breton, 1981: p. 8).

This is the place to point out that the thesis advocated by J.-Loup Amselle and E. Mbokolo (1985: p. 43) that ethnicity is a colonial fabrication doesn't seem valid. Indeed, as long as human groups recognize themselves through the centuries 
in a culture as it refers to a set of traditions, values, know-how and know-how, it is obvious that this complex values cannot be realized in less than a century. Even if the social and cultural anthropology of the African peoples lacks an appropriate term for ethnicity, this cannot invalidate its anteriority to the colonial period (Zidi, 2015: p. 201). The proof of this is the formation of the Kongo ethnic group. Analyzing methodically the way the Kongo ethnic group formed, J. Zidi (2015: pp. 201-202) argues:

"In both space and time, the lineage (moyo) kongo lineage nucleus, as a natural structure, became denser, more complex, and gave rise to a larger spatial and demographic structure: the clan (kanda). It is from this level of socio-political organization that already presupposes the establishment of social and legal standards of life that the process of birth of the Kongo ethnic group took place. First there are three: Nsaku, Nzinga, Mpandzu; then twelve, over time the merging of the clans gave birth to a large socio-political group: the ethnic group".

Obviously considered in the African context, the formation of an ethnic group isn't, ultimately, a spontaneous generation. It is part of the long term at the price of multiple resistances due to the vagaries of history. These resistances helped to shape a collective consciousness foundation for a shared identity. In fact, ethnicity refers to

"A human group historically constituted on the basis of customs and values commonly lived and shared and especially the consciousness and the feeling of a particular identity. In this sense, the nation is distinguished from the ethnic group by the existence of a legally defined territory within which coexist human groups (ethnic groups) having beyond their specificity, a common cultural background" (Kouvouama \& Dacy, 1985: p. 281).

This ethnic consciousness and this feeling of particular identity fundamentally structure the imagination of the peoples concerned.

However, ethnic affirmation, still called ethnic identity or consciousness, doesn't refer to ethnocentrism. In fact, ethnocentrism is, fundamentally, the doctrine that advocates the primacy of an ethnic group or ethnic group over the rest of country at the fourfold political, economic, social and cultural levels (Kouvouama \& Dacy, 1985: p. 283). From this perspective, ethnocentrism refers to the instrumentalization of this ethnic consciousness by political groups struggling for the conquest and preservation of political power (Kouvouama \& Dacy, 1985: p. 283).

In sum, ethnocentrism is a more or less conscious tendency constitutive of our first humanity from which we understand and judge others according to the values that the parents and the immediate environment have transmitted to us. In other words, "ethnocentrism consists in seeing things by making the group to which one belongs the center of everything, the other groups being classified and evaluated in relation to it" (Carfantan \& Condamines, 1980: p. 167). The ethnocentric approach takes the culture of its ethnicity, its tribe as paragon, model. Therefore, the values that structure our personality, our identity are considered better and more capable of, and hence superior to, values of other ethnic groups. 
Such an approach places those who are not from our tribe/ethnicity, as well as foreigners, in position of inferiority to us. They are therefore undervalued. With ethnocentrism, it is a question of self-affirmation of one's identity or of the identity of the group to which one belongs. However, if this self-affirmation, as soon as one thinks of it, allows oneself to be discovered under the mode of denial or devaluation of other ethnic groups, how is the concept of nation understood?

\subsection{Nation}

The nation is understood to mean a human community bound by the consciousness of history, culture, common language and shared traditions. The peculiarity of the nation is then the inheritance received, an inheritance that all people claim. In other words, the nation is the living community of past heirs, present and future. It involves a dimension of solidarity in time and space, what is called the community of destiny.

The philologist and historian of religions, Joseph Ernest Renan defining what he meant by the term "nation" emphasized that:

"A nation is a soul, a spiritual principle. Two things which, to tell the truth, only make one: constitute this soul. This spiritual principle. One is in the past, the other in the present. One is the common possession of a rich legacy of memories; the other is the present consent, the desire to live together, the will to continue to assert the inheritance that has been undivided" (Renan, 1882: p. 50).

Ernest Renan highlights here, in a heaped way, the characteristic principles of nation in the original sense of the term. Indeed, nation isn't a spontaneous generation. She is a soul, that is, a spiritual principle. Two constitutive elements characterize this spiritual principle. The first refers to shared common memories; the second shows the existential momentum of continuing to live together. However, it must be pointed out that while the first constitutive element of the soul of nation refers precisely to the past, the second is related to the future. This future only makes sense if the men, the heirs who are supposed to perpetuate this heritage, are animated by a sincere desire to be guardians of the temple, as they say, of the heritage received. The nation is a legacy and at the same time a project. Indeed, the immense legacy received cannot be kept indefinitely. It could, depending on the circumstances and the time, undergo changes always in the sense of the preservation of the common good and, therefore, of the whole political community. However, the preservation of this rich legacy requires a daily battle of all members. Because, since the human being is a perverse being precisely because the perversity is consubstantial with its finitude, increased vigilance must be observed so that the societal balance isn't undermined by deviant behavior. The respect of the norm governing the society must thus be the fight of all and everyone to allow this project, the nation to be perpetuated.

The nation is then the result of a long process of maturation of the collective consciousness, of strengthening of the affective link between the members com- 
posing this political community. It is at the price of a thousand and one sacrifices that a people becomes a people. "To have common glories in the past, a common will in the present; to have done great things together, to want to do things again, these are the essential conditions for being a people" (Renan, 1882: p. 50).

Obviously, as a result of a dream, but a common dream, the nation is a "collective will”. A priori, it is neither a creation of law nor a legal institution, but a sociological and political reality. In a remarkable study of the difficulties that the African nation-states have to build real states on the centralized model of the masters of yesterday, substituting, by displayed voluntarism, to ethnic and regional solidarities, a true solidarity, Thierry Michalon (1984) writes: "The nation, a cultural and emotional phenomenon, is therefore formed only very slowly, very gradually, over generations. It is by sharing the same story for at least one or two centuries that we feel this community feeling" (p. 24).

In this perspective, the unity of the nation remains based on a historical continuity, a destiny, a common ideal to achieve. One can therefore wonder: The aggregates of Africans living in geographical areas whose territorial limits were fixed and imposed by the Berlin Conference of 1884-1885, which was held in the absence of Africans, have they a common past and/or do they really constitute nations? Is the repeated appeal of the fathers of independence to "unity" not in the construction of this nation? On the other hand, has not African soil given birth to great nations whose radiance has been recognized by the whole world?

\section{Ignorance and Destruction of African Nations by the Colonizing West}

\subsection{Historiographic Analysis of the Nation}

Questioning about nation-building in Africa cannot ignore its colonial past. As much as the present situation in Africa is dependent on this past, so much is the debate on formation of the unitary state an alien fact. To understand why the debate on the construction of the nation arises for more than fifty years in Africa with what it involves as collateral effects ("ethnic" wars), this is the challenge we will develop here.

In an informative article entitled "Africa or lost identity", and in its first point “A history thwarted by the West", E. Kotto Essomé (1978: pp. 44-45) put:

"The history of Africa does not begin with that of its discovery, then its colonization, by Europe. The continent, which the Portuguese merchants in search of the spice route, will approach in the sixteenth century, had already, like Europe, its sovereign states and original institutions that the colonizers will ignore".

KottoEssomé's statement on the current state of Africa is revealed, in analysis, as the lawsuit filed against the West. Indeed, the current state of Africa, according to KottoEssomé, doesn't coincide in any way with the previous situation be- 
fore meeting with Europe, but rather proceeds from what is known as the clash of civilizations. As far as we can go back in the past, it is clear that originally, Africa was divided between four major cultural and historical areas, enumerated by Kotto Essomé (1978: p. 44): a first Sudanese area which successively encompasses, between the 7th and the 12th century, the Kingdom of Tekrur (along the Senegal River), the Ghana Empire (between the rivers Senegal and Niger), the Hausa kingdoms (between the River Niger and Lake Chad), the kingdom of Kanem (north of Lake Chad) and the empire of Mali (instead of Ghana); a second area that forms along the Guinean band with the founding of Benin kingdom; a third zone (the southern equatorial strip) the Bantu people; finally, fourth largest area formed by East Africa, of which its particularity is to have resulted in mixtures with the Arabs, Persians, Indians and Indonesians even for Madagascar.

These great cultural areas are unique in that they had developed powerful sovereign states where life was good.

In any case, it was never possible to see recurrent wars between the different peoples evolving in these different cultural areas as Europe knew them; even less to hear a speech tending to emphasize that those peoples were dying of starvation.

Until now, the African people lived in a completely peaceful way. With the exception of the battle of Kirina of 1235, opposing, Mali, Soundiata (Sunjata) Keita Sumangoro (Sumaworo) Kante, which ended in the victory of Soundiata, and, among others, the no less important that took place in the old Kongo kingdom, called the battle of Ambuila, which took place on October 29, 1665, the rivalries that could be born within African cultural and historical areas were quickly settled by the Sages, guardians of the tradition. These states/or kingdoms were very well administered. The inhabitants had a sense of political and administrative organization which had nothing to envy to that of the European states of the time. One of the great African historians, J. Ki-Zerbo (1994: p. 140) portrays the Mali Empire in a striking light and compares it to a mango, composed of a hard central core (under the direct administration of the king), a pulp of kingdoms held in a strict dependency and a peripheral zone with subordinate kingdoms. In short, it is a very "decentralized" kingdom.

The Malian state, as we know, elaborated during the reign of Soundjata Keita, the MandenKalikan (Mandé's Oath), or Mandé's Charter. This charter dating from the thirteenth century is truly the first statement of human rights. From memory of the world, nothing of this kind had been promulgated before. If we believe Francis Simonis, who himself reports the words of the Malian researcher, Youssouf Tata Cissé, this charter has had various names:

"First called Donsolukalikan, 'Oath of Hunters', then Dunyamakilikan, 'Injunction to the world', this declaration was solemnly proclaimed in Dakajalan, the first capital of the empire of Mali, under the name of MandenKalikan, the Oath of Mandé. It was the day of the enthronement of SoundjataKeïta, the founder of the Mali Empire. We are late 1222 [...]" (Simonis, 2015: p. 9). 
Note also that when it was promulgated the day the mysterious Emperor of Mali took the reins of power, an equally historic event manifested itself in the starry sky of Mali. This is the passage of the Halley Comet in this year 1222. Sheltered from any foreign influence and without any mimicry, this charter designed by Africans living on African soil has seven words, which are as many headings of articles of the charter (Tata Cisse, 1991). The first paragraphs of this charter stipulate:

All (human) life is a life.

It is true that a life appears before another life,

But a life is not more "old", more respectable

That another life,

Just as a life is not superior to another life.

Hunters declare:

All life being a life,

Any harm done to a life requires reparation.

Therefore,

Let no one take his neighbor for free,

Let no one harm his neighbor,

May no one martyrise his fellow man. (Celhto, 2008: p. 147).

This charter of obvious modernity puts the notion of justice at the heart of the political community. It is justice, and it alone, that must govern human relationships. It is from her that good understanding and good living together depend. Nobody can therefore do justice and especially take the life of another person. Justice is the foundation of everything. This statement raises the question: Does contemporary life rest on justice? Nothing is less truth!

As far as the ancient Kongo kingdom is concerned, the testimony of ethnologists and other missionaries is equally remarkable for the greatness of the civilization they had just discovered. According to C. A. Diop (1979), Leo Frobenius, who had not succumbed to the prejudices of his time, had emphasized the existence of well-ordered and civilized states, powerful rulers and opulent industries.

As we can see, African states had nothing to envy of Europe. Throughout Africa, people had developed rules of life codifying laws beyond which no one could derogate. In the Horn of Africa, for example, the Somali have developed, since ancient times, the Xeer, a code of laws that delimits the rights and duties of each person (Ali Moussa-Iye, 2014). In this Xeer, there is a clause relating to categories of persons who must imperatively be protected in case of war:

"Somali pastoralists (...) have, for example, developed rules of war of astonishing modernity. These rules identify certain population groups called 'Birmageydo' (those that no weapon should touch) that are spared and protected in the event of war. This category includes women, children, the elderly, but also the Sages, men of science and religion, guests and all those who are strangers to the conflict. Dignity and certain rights of the wounded and prisoners of war are also defended in this 'Geneva Convention' before the time" (Mous- 
sa-Iye, 2013: p. 1).

\subsection{Irrealism and Ignorance of Western Thinkers}

This is the place to recall that the foggy speculations of Hegel and Nicolas Sarkozy, ancient president of France, presenting Africa as an a-historical continent do not stick to reality. If the first, Hegel (1967: p. 76), qualifies the African savage because on the threshold of history: "The African, in his concentrated and undifferentiated unity (...) represents the natural man in all his savagery and his petulance"; the second, Sarkozy considers him an atypical being who lives an existential drama precisely because he "has not gone far enough into history". Such utterances uttered in the worst ignorance of African history unquestionably reflect intellectual blindness sprinkled with the racist education hints of their authors. These words are the basis of "the negative ontology of Africa" (Kounkou, 2010: p. 1). Indeed, far from being a continent formerly inhabited by barbaric hordes characterized by "the most unreflective cruelty and the most repugnant brutality" (Hegel, 1967: p. 75), Africa has had men of value whose excellence has been recognized and repeated a thousand times by non-Africans of high intellectuality ${ }^{1}$. The legendary rush of Greek thinkers in Egypt to drink at the source of knowledge that no other civilization offered at the time is the most obvious proof that Africa was not a terra incognita. Among the men of culture who have marked the intellectual history of Africa are, among others, Akhenaton, whose real name is Amenophis IV. Founder of The Amarnian School, he left a text of exceptional depth called The Anthem Aton. Sekmuphis and Psenopis are the great thinkers who taught at the Heliopolis School of Philosophy. It is this school that has discovered for the first time in the world, the principle of the original chaos called the Nun.

Embroiled in a smug narcissism, the West, since the Enlightenment, always presents itself as the most accomplished figure of the universal. He appreciates not without detours the other cultures in position of overhang, and builds theoretical lucubrations of a negative otherness to justify his domination. This is why A. Moussa-Iye (2013: p. 1) states that "the cliché 'hordes without faith or law' is a lamentable propaganda of the European colonizers unable to understand societies structured differently from their own and especially pressed to find justifications for their colonial order".

However, the most legendary peace that reigned in African states will be almost brutally broken. Indeed, the decadence of the Roman Empire will have a resonance on the brilliant African kingdoms. The new moneymakers, under the thumb of the Catholic Church, will launch into international trade, in search of

\footnotetext{
${ }^{1}$ Solon (638-559 BC), a student at the school of Sais where he had as master Sonchis, one of the Seven Sages of Greece, politician and legislator, founder of the Athenian democracy, is among those who have not had a state of mind to recognize it: "Solon told me that he was received with great honors, and that having one day questioned the antiquities the most paid priests in this matter, he had discovered that neither he nor any other Greek had any knowledge of it" (Plato, Timaeus, Translation, notices and notes by ÉmileChambry, Bibliothèque électronique du Québec Philosophy Collection Volume 8: version 1.01.59).
} 
new lands. It is in this context that

"From 1450, the arrival of Portuguese ships Barthélémy Diaz and Vasco de Gama will disrupt the history of the continent. The first navigators first found counters along the coasts where they barter. But from the sixteenth century, needing additional labor for their mines in the Americas, the Portuguese began the slave trade. Entire regions of West Africa will be depopulated from the moment other European navigators engage in triangular traffic (Europe-Africa-America)" (Kotto Essomé, 1978: p. 45).

Since then, the fate of Africa has been sealed. European nations with the superiority of their firepower, will begin to break any resistance of Africans within these new territories passed under their control. It was this logic of resistance that led the young Kongo, Kimpa Vita, "the Joan of Arc of Africa", to be condemned to the stake ${ }^{2}$.

The rivalry between the powers will culminate in 1884, in Berlin, by the holding of an international conference under the aegis of German Chancellor Bismarck. Its purpose was to rationalize these annexations more easily by putting a little shape. During this conference Africa, absent, will be shared between powers and its disarticulated sociological structures. Indeed, this "balkanization" will not take into account regional balances, let alone linguistic, cultural or ethnic affiliations. What prompted, according to E. Kotto Essomé (1978: p. 47), the indignation of the Africanist Robert Cornevin. Thus, "Somalis [will] be dispersed despite themselves in four states declared different" (Kotto Essomé, 1978: p. 54), the Kongo in six states, etc. A policy of assimilation will be imposed on all African States.

But time being the grand master of everything, the wind of freedom whose dynamics was punctuated, around the years 1890-1920, by the black literary movements, namely the "Niagara Movement" (WEB Du Bois), "Come back Africa-African Blacks Return-(Marcus Garvey)," The Negro-Renaissance "(Langston Hughes, Claude Mac Kay, Cullen Countee, Sterling Brown, Jean Toomer)," The Negritude “(Léopold Sédar Senghor, AiméCesaire, Leon-GontranDamas)", will be right about this system of depersonalization of the human being: colonization. These movements of claiming the rights and the dignity of the black man will lead to decolonization. In the end, was not this decolonization an insidious trap for Africans?

\section{Advent of Decolonization}

\subsection{De Gaulle and the Trap of Independence in French-Speaking Africa}

When the wind of decolonization blows, the French political class was feverish at the idea of granting independence to the former colonies. General de Gaulle was

${ }^{2}$ Regarding the circumstances of his ordeal, read AnselmeMbemba-Mpandzou, "The decadence of humanity in Nietzsche and its implications for the development of Africa. A Critical Study of Globalization", PhD Thesis, Brazzaville, Faculty of Arts and Humanities, Marien Ngouabi University, 2015, p. 312. 
fiercely opposed to the conference of Brazzaville in 1944, but by "the pressure of the international environment and the struggles within the colonial empire" (Nanga, 2006: p. 3), the African states from Berlin, still have access to "autonomy"3. To stem any desire for independence, General de Gaulle introduces into the constitution a new provision that will force the former colonies to be in the "Eternal and Fraternal Community whose borders will go from the plains of Flanders to the forests of the equator", which was adopted by referendum in 1958 (Nanga, 2006: p. 2). But, little by little, the thirst for independence continues to win the African people. It happens that from 1946 to 1960, a "transition to neo-colonialism", that is to say, during this period.

"Independence is no longer considered incompatible with the existence of the Community, dear to de Gaulle, Mitterrand and Houphouet-Boigny. 'A Member State of the Community, now admitting Article 86 of the Revised Constitution, may also by agreement become independent without thereby ceasing to belong to the Community'. Countries are independent but still members of the Community dominated by France, this is the true status of the new States" (Nanga, 2006: p. 2).

The year 1960, is the historic year when the countries under French domination will reach independence. This one will not really be one, since France anxious to perpetuate its "Community", will put in place other mechanisms of domination "Through many agreements (economic, cultural, military, political) concluded with the elites local, co-managers of the transition to neocolonialism (1956-1960), and multiple institutions" (Nanga, 2006: p. 2). One must have an obtuse mind not to understand that General de Gaulle, in a very cynical and deliberate way, had trapped the new African states. From the "Cooperation", survival of the famous "Community", to the "African cell of the Elysée" created by General de Gaulle, "the metropolis was able to maintain the dependencies of the" former colonies (Nanga, 2006: p. 3). It has therefore placed at the head of new "independent" African states "puppet" governments, most often led by puppets chosen from the fringes of the most docile population, to perpetuate the system of resource predation. These puppets play the role of "new slavers". That said, independence has never been more than formal. Indeed, in fact, sovereignty does not exist, and, no doubt, will never exist as long as Africa continues to be dictated the path to follow by French and/or Western policies. The metropolises under North control (France in the lead) and manage everything through mafia networks. These work like a spider's web. As much as they are the king-makers, so much they ensure that the local powers directed by "new slavers" that they have placed themselves are destabilized. In other words, the western chancelleries watch over grain in the name of the sacrosanct principle of stability. If the "new slavers" enjoy the favor and protection of the lobbies of yesterday's mas-

${ }^{3}$ One of the recommendations of the Brazzaville Conference of 1944 states that: "The ends of the work of civilization accomplished by France in the colonies discard any idea of autonomy, any possibility of evolution out of the French block of the empire, the possible constitution, even remote of salt-government in the colonies Is to be drawn aside" (Nanga, 2006: p. 2). 
ters, it is not because they are more capable and intelligent, but because they are, obviously, "More malleable, docile to the point of starving their peoples by allowing the multinationals of the North and certain groups named" nationals "to plunder the resources of their own countries whose destinies they preside." (Mbemba-Mpandzou, 2015: p. 366).

In short, by accepting to play the game of northern lobbies, the "new slavers" are not in the service of their people, their "nation", but in the service of foreign powers whether Western or Asian. The longevity of some of our "Heads of State" can be explained by the fact that they manage and protect the interests of these foreign powers better that goes without saying. "The independent state thus continues the colonial state. He remains separated from the people. There is a divorce between the state and the nation" (Conac, "Preface", in T. Michalon, 1984: p. 9). Thus, reinforced by the foreign umbrella, African leaders become deaf to the misery and cries of terrible suffering of their people.

\subsection{African Heads of State and the Perpetuation of the Neocolonial State}

It is therefore to these categories of individuals whose past and profile meet the criteria of the masters of the world that Western mafia networks prefer to entrust the state's responsibilities in Africa. Those of our well-educated intellectuals, coming out of their renowned alma mater with a proven sense of responsibility for Africa, do not enjoy any of their trust. Why? Simply because they do not fit, according to them, into the cast of leaders who can be placed at the head of the dominated countries. However, as long as these "new slavers" account only for the foreign powers from whom they hold their legitimacy, they set up a whole system of patronage, cement of the postcolonial state, on which they will cynically rely to sit their power and rule the state. However, the type of state they are going to have to lead is not the unitary state as we observe it in Europe where it was initiated and/or, proportionally, it works perfectly, but a type of state qualified as nation-state. The fundamental characteristic of the nation-state is that it is a state that does not cover a single nation, but encompasses heterogeneous populations and has centralized institutions (Michalon, 1984: p. 28). But "by the cunning of colonial grammar" (Nanga, 2006: p. 3), this type of state has plunged and plunges many African populations into a kind of discomfort for two reasons. The first reason is ideological. Indeed, the nation-state as an imported state, as B. Badie (1992: p. 244) puts it, does not rest on any foundation: it is artificial. It is all the more artificial because it comes from a logic that plays with African cultural traditions. Indeed, following the decadence of the Roman Empire around 476, micronationalities were formed administered by lords. In time, these gave rise to what is now called the European nations. So it took a long process of maturing collective consciousness for these European nations to take shape. Their formation was neither the will of an external authority nor the bitter consent to a diktat. According to P. Fougeyrollas (1987: p. 25), the nation has neither been nor is nowhere the result of a contract expressed or even tacit 
between individuals or groups wishing to associate. The representative cultural community of the nation is only the tip of the iceberg, the foundations of which are quite unfathomable, even if one finds that its crystallizing force is both economic and political.

Whereas in Europe, proportionately, the Nation preceded the state, in Africa, the colonizing powers, reversing this logic, erase any previous socio-political organization that was the pride of the African peoples; they impose a new order which makes it possible to first create the state before the nation. It is as if the Nations never existed in Africa. What ignominy? The second is cultural. This new (neocolonial) state forced populations with heterogeneous habits to cohabit with those who had much more civilized customs even though they do not belong to the same system of values. This is why interethnic solidarity is never at the rendezvous. In any case, the decision makers do not make it a concern, since they have taken over from the colonial state that was maintained during the colonial period through this logic of "divide and rule". The central "state" that was to federate the different real and regional solidarities exacerbates the ethnic divisions, thus creating identity tensions. The ethnic group to which the regime's opponent belongs to the absolute evil that must be eradicated at all costs; among others, the cases of Rwanda in 1994, Congo-Brazzaville in 1993, 1997, 1998-2000, the Central African Republic in 2013, etc., are representative of this drift. For nothing to be blamed, the group that serves as a scapegoat feeling frustrated, takes refuge in a position of withdrawal identity, which can result, if the central power pushes the plug a little far, the creation of groups of $d$ self-defense or militia. However, the creation of militias is an unexpected opportunity for those who hold the reins of power, especially if they enjoy the support of the international community as is often the case. Since "the army, the management institution of the postcolonial state, has no vocation to make war" (Yengo, 2006: p. 311), since it is fundamentally a column of the armies of the metropolis, the power proceeds, too, to the creation of militia. There are situations where in some countries the state deliberately manipulates young people from the opposite camp by inciting them to carry out very serious acts, simply to bring the responsibility to the adversary in order to drown it better, a pretext that is appropriate to proceed with ethnic cleansing. Holders of legitimate violence multiply strategies for liquidating opponents and their supporters with targeted kidnappings and assassinations. Sacks of Nguiri $^{4}$ out of the public treasury, bleeding him to the blow, to maintain his militias in which many young people without perspective, are enlisted, yielding to the sirens of the food politicians in need of vision, philosophy of development for their people. The goal is to defend, it is said, the power of the tribe. What is paradoxical is that these African heads of state, during their investiture, hold before the diplomatic corps and the notables of their respective countries a unity speech calling the girls and sons to join them so that together they can build the nation and develop their country. Strangely

${ }^{4}$ Vegetable fiber bag used for storage of cassava flour. 
enough, when the time comes when they must report to the people, power ceases to be a power of the people to become a carnivorous power determined to crush the people. All this is happening under the watchful eye of the "intellectuals", the very ones who should be the bad conscience of the republic when it goes bad. By observing the silence before the crimes of all kinds, in fact, these "intellectuals" are accomplices of all the drifts orchestrated by the postcolonial powers. Moreover, it could not be otherwise since they are at the origin of the manipulations of Constitution, the bible of the nation, with all that this entails like tragedy.

\section{Perspectives: For an Individual and Truly Human Commitment or the Birth of the African Subject}

\subsection{Place of Education of the Rulers in the Subjugation of Africa}

Africa is badly governed. It is all the more badly governed that it is held hostage by the powers of the North, but with the proven complicity of local mercenaries (the lizard only enters a wall when it is split). The rulers shine with an insane irresponsibility bordering a deficit of vision. Their disobedience should be, to paraphrase Foucaldian Frédéric Gros, a shared and burning emergency. For relearning to disobey is, more than ever, necessary and urgent. It is the step that leads to dignity and to making one become a subject of history. We know that the concept of subject goes back to Descartes with the discovery of the ego cogito. The ego cogito occupies a central position in the order of reasons in that it provides a foundation for a major epistemological project known as mathesis universalis. For the most part, Western philosophy apprehends the subject in his dual determination to be both man as an individual and the support of universal thought. But the African, in general, has unfortunately not yet integrated the universal dimension in his action.

The confusion between the singular and the universal still has good days in the tropics.

Indeed, the African individual as he sees himself today, is not yet a constituted subject. The education he has received in his many ethnic and regional affiliations that form his identity cannot make him a subject with whom "an ethical encounter is possible". His consciousness is still focused on immediacy, that is to say, what is common between man and animal, and on ethnocentric values to the point where it is difficult to get out of the grip clan. To attain the status of subject, the African must eliminate its singularities and objectify itself, rising to the universal. Indeed, the true being of the subject, emphasizes De Buzon (1988), is to be exceeded by the catharsis of the first illusions. For the true dimension of being of the subject is obtained, at least partially, when the first ideas that we thought were personal disappeared, whereas these were transmitted to us by the clan and/or the tribe.

As long as his consciousness remains phagocyted by the power of the tribe, he will not be able to access the autonomy of thought, let alone integrate republican values. When autonomy is built, the subject is able to assert his rights. Not only 
does he become subject to rights, but he refuses to fall under the domination of anyone. His thought becomes critical. It is all the more critical because it "no longer receives its norms and laws from the nature of things (Aristotle) or from God, but bases them from reason" (Renaut, 1988: p. 68). It is then that he is safe from the manipulations of the indelicate and cheating politicians who make him believe that "there is a community of interests between them and him" (Kouvouama \& Dacy, 1985: p. 283).

These misleading statements by these politicians should give reason for and encourage those who listen to them to reconsider their position vis-à-vis them. Because, the monstrosities that serve us African leaders and all the cohort of food politicians who have taken up the cause of belly dancing enjoin us not to condone their cynical policy. It is therefore to take hic and nunc our responsibilities to "reinvent humanity". In his book Désobéir, Frédéric Gros (2017) returned to the "cry of scandal La Boétie face the monstrous enigma of politics, which is our ability to accept the intolerable, to support the growing indecency of world". At the time of the publication of this work, in any case the author granted an interview to Sonya Faure in which he recalled that to be a political subject, it is precisely not to avoid the call to act, to denounce, to refuse. It is here that contribution of political subjects and/or intellectuals is most expected. Indeed, an intellectual refuses to give his guarantee to a carnivorous power and close his eyes in front of "mountains" of corpses of compatriots. An intellectual can not perpetually continue to support leaders who have come to the management of the city only to steal, kill and destroy. Moreover, the fact of being of a high intellectuality constinue in itself a principle of exclusion to the adulation of heads of state resembling directors of opera singing "marchons, marchons", while remaining on square.

\subsection{Responsibility of African Elites and Efforts to Build African Social Space}

The misfortune of Africa, we think, is that Africa has no more elites: after Kwame Nkrumah, Sheikh Anta Diop, Oum Ndigi, Theophile Obenga, Mubabinge Bilolo, without forgetting Mongo Beti (died in poverty and the utter indifference of African intellectuals), Africa is out of reach of intellectual elites capable of confronting the West who is truly our great enemy.

Are we born to be in the pay of the West? How many Africans must die so that we can become aware of our destiny? Is not five centuries of colonization enough to reevaluate our relationship to the world? After so many wars and unspeakable killings of Africans beyond the limits of the "tolerable", is it not time for us to come together to rebuild our countries, and thus lay the foundations for Africa's tomorrow? There are two possibilities for Africa. Either one stands up as one man to question the sacrosanct principle of the intangibility of the borders, thus returning to the old configurations of before colonization, which, obviously, will require the convocation of Berlin II Conference, or violence is done by changing our mental software. This implies then, the refusal to go flatten out at 
the manger and give in to ethnocentric calls politicians in need of vision.

To succeed such a bet presupposes a critical distance from the system of dominant ideas that emerge from neocolonialism, neoliberal globalization, tribalism or ethnocentrism. Indeed, these ideas pollute our mind and put our freedom to think under the extinguisher. This is an opportunity to highlight how much Frédéric Gros's work, Désobéir, is, as its title suggests, a great remedy for disobeying the deadly instructions of food politicians and other pseudo-intellectuals living greatest evil of Africa. When we hear people say, "We have the power, the power belongs to us", such a statement slanders against a fundamental democratic principle, namely that in a democracy the characteristic of the exercise of power is to be ephemeral. This is the conclusion that Marx, in The Civil War in France, has reached. Analyzing the greatest revolutionary event that overthrew the nineteenth century, namely the Paris Commune, Marx (1968) argues: "The Commune was composed of municipal councilors, elected by universal suffrage in the various districts of the city. They were responsible and revocable at all times" (p. 41). What the Paris Commune has shown is that, that is, the holder of a political mandate is subject to the principle of permanent revocability. Outlines through this principle the idea that the place of power is unoccupable. Because we only install it to leave it (Kounkou, 1999).

That said, any political game that does not rely, among other things, on the principle of the unoccupancy of the place of power, becomes unquestionably a dictatorship. It is when one is prey to an inner spiritual emptiness that one is led to believe that one is the representative of one's tribe. Such action amounts to making the nation's construction a sea serpent. In fact, one cannot build the nation on the basis of tribalism or ethnocentrism. Ethnocentrism is at most an ideology insofar as it is incapable of "revealing its own determinism" (Mannheim, quoted by L. Fidès, 2014: p. 9). However, ideology is by definition a discourse that conceals its own process, its true nature which is to be a justification without justification, that is to say it camouflages its origin (Fidès, 2014: p. 9).

Consequently, the ethnic management of certain African powers and the lack of recognition of the ethnic identities of human groups sharing the same territorial space make the bed of the dictatorship and, in the long run, send back the construction of the nation to the Greek calendar. It is obvious that this dictatorship cannot allow the construction of the nation, since the characteristic of a dictatorship is to muzzle all freedom so that all free thought cannot emerge. As long as a power is maintained by stifling human reason, it becomes a monstrosity that must lead to revolt (De La Boetie, 1976: p. 28). So, the question is, how can we build the nation, a societal space where everyone can feel safe, enjoy the same rights and benefit equitably from the same advantages as others?

The first effort that every patriot (African) must provide is to be violent while keeping his freedom of thought. Keeping one's freedom of thinking means thinking for oneself. This means that the truth that we perceive ourselves is more just than the truth that the illusion merchants compel us to believe. Indeed, "When we are forced to think in a certain way, it is the thought that is sup- 
pressed, because we think only freely: a thought caused by something other than itself is not a thought." (Fidès, 2014: p. 7). Then never give in to the sirens of ethnocentric mercenaries in the pay of the West even if the viscera have no juice. The village conformism is a major obstacle in the way of the recovery of our dignity, of our humanity. Finally, it is therefore obligatory for everyone to give up giving up politics. Politics is too serious a thing not to leave it to impious souls. Indeed, and this is an idea dear to Hannah Arendt: "as men stop thinking and especially to speak in the public space we will not be safe from barbarism" (H. Arendt, cited by Coll, Annie (eds.), 2006: p. 1). Totalitarianism flourished thanks to "total indifference to politics, linked to the feeling of its greatest impotence" (Arendt, cited by Coll, Annie (eds.), 2006: p. 2). Never to discard others, this must be the course of action for everyone. Moreover Hannah Arendt who has better studied the totalitarian phenomenon has left this sentence full of depth:

"Each man is the bearer of an irreplaceable singularity that must manifest in the public space so that the concept of freedom still has a meaning."

In other words, only the fact of taking the floor to finally seize the political thing, to discuss the common affairs, can free us from the conformism of the mass. To come to the world is to be confronted with plurality, it is a new hope that arises as it is true that "men are not born to die but to innovate". (H. Arendt, cited by Coll, Annie (eds.), 2006: p. 3).

Antisthenes wise advice that "a man of more than a parent must be estimated" (Laërce, 1965: p. 11) should be the norm. From experience, and it is a consistency especially among Africans, people prefer to support a parent to preserve their interests even though the latter is a criminal born, murderer and thief.

\section{Conclusion}

Ethnocentrism, the existence of corrupt powers in the pay of former colonial countries in Africa has been the subject of several studies in the early years of independence. Our work questions the concepts of ethnocentrism and nation in order to identify, on the one hand, the universes of meaning they contain and, on the other hand, the obstacles that mark the nation's construction path by preventing the birth of the nation. At the end of our reflection, we showed that in the African territorial space, men had to confront, before their encounter with Europe, the vicissitudes of life, which gave rise to the appearance of a number of peoples and ethnic groups with rather heterogeneous mores. These human communities have left a precious capital of inheritance at once material, spiritual and moral. A tragic blow of the lot made that these are condemned to cohabit together in artificial spaces with well-defined outlines. But the rejection of the norm, the absence of common thought, of common justice, in short of a common ideal, has fundamentally eroded the formation of a common identity beyond the diversity of cultures. The selfishness of some and the immoderate desire to accumulate the wealth of others quickly brought to the surface the "monstrosity nested in each of us" creating an unfortunate precedent. Despite 
their greed for power, politicians have not yet been able to embody the nobility of heart that attaches to their responsibility. Such irresponsibility undeniably delays the advent of the African subject, and, in turn, the building of new nations in Africa.

It is therefore urgent in the current global context that Africans can, in a sincere patriotic impulse, fight against ethnocentrism, the post-colonial state headed by the "new slavers", servants of neoliberal imperialism. For it, the categorical refusal to submit blindly to the barbarian directives of the superiors, when they are not in harmony with the constitution of the country and/or undermine the dignity and the rights and liberties of the individual, is imperative for everything citizen and must become a cardinal principle to which no one can derogate. It is by combating these obstacles that are as many major obstacles to the advent of the national consciousness that Africa can strive towards the construction of real states, and eventually engage in the process of emergence. Of all these obstacles to combat, the greatest is tribalism, rooted essentially in the manipulation of prejudices and tribal hatreds for purposes of conquest and the preservation of power. Obviously tribalism is a poison in that it undermines societal balance and presents the "tribes" as rival communities when it has never been so. Before the meeting with the West, African communities were not in permanent war. There was a legendary agreement between them. It is the West, with its mercantile policy of "divide and conquer", which introduced the notion of "tribe" to think about otherness. It is from this representation that Africans have come to perceive and hate each other. So much so that the African's look at the African has become a murderous look that puts his compatriot on notice to choose his side, as they say. Such an exclusionary approach puts at bay another person instead of building a bridge. By changing our gaze towards our compatriot, is not this a way to attract him towards us and free him from the weight of the clichés in which we have locked him up?

In the current configurations of African "states", one cannot build the Nation without the contribution of all ethnic identities. And if "to open a school is to close a prison" as Victor Hugo has well pointed out, the school must so be the crucible from which the so-called change of mentality will start, a thorough overhaul both of the institutions of the republic and educational programs that must take into account the realities of Africa and adapt to the challenges of the world today. But parents must lead by example, especially those who do belly politics. In short, the food politicians who are the biggest criminals, crooks and power junkies, thieves and real gravediggers of our "republics", cannot contribute to the emergence of Africa and therefore to the birth of the African subject.

\section{Conflicts of Interest}

The author declares no conflicts of interest regarding the publication of this paper.

\section{References}

Amselle, J. L., \& Elikia, M. (1999). Au cœur de l'ethnie. Paris: La Découverte \& Syros. 
Amselle, J. L., \& Mbokolo, E. (1985). Au coeur de l'ethnie. Paris: La Découverte \& Syros.

Badie, B. (1992). L'Etat importé. L'occidentalisation de l'ordre politique. Paris: Fayard.

Berger, P., \& Luckman, T. (2006). La construction sociale de la réalité. Paris: Armand Colin.

Breton, R. (1981). Les ethnies, Que sais-je? Paris: PUF.

Carfantan, J. Y., \& Condamines, C. (1980). Qui a peur du Tiers monde? Paris: Seuil, Collection Points.

Celhto (2008). La Charte de Kurukan Fuga. Paris: L'Harmattan.

Chrétien, J. P., \& Prunier, G. (Dir.) (1989). Les ethnies ont une histoire. Paris: Karthala.

Coll, A. (Dir.) (2006). Arendt Hannah, ou l'amour du monde, $N^{\circ} 90$.

https://www.icem-pedagogie-freinet.org/sites/default/files/N90_HArendt.pdf

De Buzon, F. (1988). L'individu et le sujet. In E. Guibert-Sledziewski, \& J. L. Vieillard-Baron (Dir.). Penser le sujet aujourd'hui (pp. 17-30). Paris: Méridiens Klincksieck.

De LaBoétie, E. (1976). Discours de la servitude volontaire. Paris: Payot, Coll. "Critique de la politique".

Diop, C. A. (1979). Nations nègres et culture, tomes 1 et 2 (4ème éd.). Paris: Editions Présence Africaine.

Fides, L. (2014). Face au discours intimidant. Essai sur le formatage des esprits à l'ère du mondialisme. Paris: Toucan.

Fougeyrollas, P. (1987). La Nation. Paris: Fayard.

Gros, F. (2017). C’est confortable d'obéir. Interview réalisée par SONYA Faure. http://www.liberation.fr/debats/2017/08/30/c-est-confortable-d-obeir_1593054

Hegel, F. (1967). Leçons sur la philosophie de l'histoire, traduction J. Gibelin. Paris: Gallimard.

Ki-Zerbo, J. (1994). Histoire de l'A frique noire, d'hier à demain. Paris: Hatier.

Kotto Essomé, E. (1978). L’Afrique ou l'identité perdue. Science \& Vie, No. 730, 43-54.

Kounkou, C. (1999). Réconciliation et démocratie comme valeurs: Le cas du Congo-Brazzaville, Texte présenté à la Réunion régionale d'experts sur l'éthique universelle à la lumière de l'expérience africaine.

Kounkou, C. (2010). L'ontologie négative de l'Afrique. Remarques sur le discours de Nicolas Sarkozy à Dakar (pp. 755-770). Cahiers D’études Africaines. http://etudesafricaines.revues.org/16349

Kouvouama, A., \& Dacy, E. (1985). Conscience ethnique et conscience de classe au Congo. Annales de la Faculté des Lettres et des Sciences Humaines, No. 1, 277-291.

Laërce, D. (1965). Vies, Doctrines et sentences des philosophes illustres, Vol. 2, livre de sixième, Traduction, Genaille, R. Paris: Garnier Flammarion.

Marx, K. (1968). La guerre civile en France, 1871. Paris: Editions Sociales.

Mbemba-Mpandzou, A. (2015). La décadence de l'humanité chez Nietzsche et sesimplications sur le développement de l'Afrique. Une étude critique de la mondialisation. Thèse de doctorat unique de philosophie, Brazzaville: Faculté des Lettres et des Sciences Humaines, Université Marien Ngouabi.

Michalon, T. (1984). Quel Etat pour l'Afrique? Paris: L'Harmattan.

Moussa-Iye, A. (2013). Le Xeer: Quels enseignements pour la construction d'une gouvernance démocratique endogène? (p. 1)

http://www.alimoussaiye.com/ 
Moussa-Iye, A. (2014). Le verdict de l'arbre. Le Xeer issa: Essai sur une démocratie endogène africaine. Paris: Editions Dagan.

Nanga, J. (2006). FrançAfrique: Les ruses de la raison postcoloniale. Contretemps, 1, 3. https://www.contretemps.eu

Nicolas, G. (1973). Fait "Ethnique" et usages du concept d “ethnie”. Cahiers Internationaux de Sociologie, 54, 95-126.

Renan, E. (1882). Qu'est-ce qu'une nation? http://classiques.uqac.ca/classiques/renan_ernest/qu_est_ce_une_nation/renan_quest_ ce_une_nation.pdf

Renaut, A. (1988). Les subjectivités: Pour une histoire du concept de sujet. In El. Guibert-Sledziewski, \& J. L. Vieillard-Baron (Eds.), Penser le sujet aujourd'hui (pp. 55-77). Paris: Méridiens Klincksieck.

Simonis, F. (2015). L'Empire du Mali d'hier à aujourd'hui. Cahiers d'histoire. Revue d'Histoire Critique, 128, 71-86.

Tata Cisse, Y. (1991). Soundjata, la Gloire du Mali. Paris: Editions Karthala, ARSAN. http://www.ac-grenoble.fr/disciplines/hg/file/pedagogie/college/.../Afrique_demarche.p dfPréambule

Yengo, P. (2006). La guerre civile au Congo-Brazzaville, 1993-2002. Paris: Editions Karthala.

Zidi, J. (2015). Entre l'ethnie et la nation: L'Etat, une impasse historique? In H. Mouckaga, S. Dianzinga, \& J. F. Owaye (Dir.), Ethnies, nations et développement en Afrique: Quelle gouvernance? Actes du colloque de Brazzaville (Congo), du 26 au 28 mai 2014. Paris: Editions L'Harmattan. 